\title{
A combined-cycle refrigeration system using ejector-cooling cycle as the bottom cycle
}

\author{
B.J. Huang *, V.A. Petrenko, J.M. Chang, C.P. Lin, S.S. Hu \\ Department of Mechanical Engineering, National Taiwan University, Taipei, Taiwan
}

Received 29 February 2000; received in revised form 2 May 2000; accepted 26 May 2000

\begin{abstract}
A combined-cycle refrigeration system (CCRS) that comprises a conventional refrigeration and air-conditioning system using mechanical compressor (RAC/MC) and an ejector-cooling cycle (EJC) is proposed and studied. The EJC is driven by the waste heat from the RAC/MC and acts as the bottom cycle of the RAC/MC. A system analysis shows that the COP of a CCRS is significantly higher than a single-stage refrigeration system. Improvement in COP can be as high as $18.4 \%$ for evaporating temperature of the RAC/MC $T_{\mathrm{e}}$ at $-5^{\circ} \mathrm{C}$. A prototype of the CCRS was built and tested in the present study. Experimental results show that at $T_{\mathrm{e}}=-4.5^{\circ} \mathrm{C}, \mathrm{COP}$ is improved by $14 \%$ for a CCRS. For $T_{\mathrm{e}}$ at $5^{\circ} \mathrm{C}$, COP can be improved by $24 \%$ for a CCRS with higher condensing temperature of the RAC/MC. The present study shows that the CCRS using the ejector-cooling cycle as the bottom cycle of the RAC/MC is viable. Further improvement in COP is possible since the prototype is not designed and operated at an optimal condition. (C) 2001 Elsevier Science Ltd and IIR. All rights reserved.
\end{abstract}

Keywords: Refrigerating system; Compression system; Ejection system; Combined system; Subcooling; Design; Performance

\section{Cycle frigorifiques mixte utilisant un système de refroidissement à éjection}

\section{Résumé}

Les auteurs présentent et étudient un cycle frigorifique mixte (CCRS) comprenant un système frigorifique et de conditionnement d'air classique utilisant un compresseur mécanique $(R A C / M C)$ et un système de refroidissement à éjection (EJC). L'EJC est entraîné par la chaleur récupérée du RAC/MC et sert de cycle d'appui du $R A C / M C$. Une analyse montre que le COP d'un CCRS est plus élevé (de façon significative) que celui d'un système frigorifique monoétagé. On peut obtenir une amélioration du COP allant jusqu'à $18,4 \%$ pour une température $T_{e}$ d'évaporation du $R A C / M C$ de $-5^{\circ} C$. On a construit puis testé un CCRE prototype lors de l'étude décrite ici. Les résultats expérimentaux montrent qu'à une température $T_{e}=-4,5^{\circ} \mathrm{C}$, le COP du CCRS est amélioré de $14 \%$. Lorsque $T_{e}=5^{\circ} \mathrm{C}$, le COP peut être amélioré de $24 \%$ pour un CCRS avec une température de condensation du RAC/MC plus élevée. Cette étude montre qu'un CCRS utilisant un système de refroidissement à éjection en appui du RAC/MC est faisable et rentable. On peut améliorer davantage le COP, puisque ce prototype n'est pas conçu et utilisé dans des conditions optimales. (C) 2001 Elsevier Science Ltd and IIR. All rights reserved.

Mots clés : Système frigorifique ; Système à compression ; Système à éjection ; Système mixte ; Sous-refroidissement ; Conception ; Performance

\footnotetext{
* Corresponding author. Tel.: + 886-2-2362-1522; fax: + 886-2-2363-1755.
}

E-mail address: bjhuang@tpts6.seed.net.tw (B.J. Huang). 


\begin{tabular}{|c|c|c|c|}
\hline \multicolumn{2}{|c|}{ Nomenclature } & \multirow{3}{*}{$\begin{array}{l}P_{\mathrm{e}}^{\prime} \\
P_{\mathrm{g}} \\
Q_{\mathrm{e}} \\
Q_{\mathrm{e}}^{\prime}\end{array}$} & \multirow{3}{*}{$\begin{array}{l}\text { evaporating pressure of EJC }(\mathrm{Pa}) \\
\text { generating pressure of EJC }(\mathrm{Pa}) \\
\text { cooling capacity of RAC/MC }(\mathrm{W})\end{array}$} \\
\hline$A_{\mathrm{e}}$ & effective area of the entrained flow of the & & \\
\hline & ejector $\left(\mathrm{m}^{2}\right)$ & & \\
\hline$A_{3}$ & $\begin{array}{l}\text { cross-section area of the constant-area sec- } \\
\text { tion of the ejector }\left(\mathrm{m}^{2}\right)\end{array}$ & $Q_{\mathrm{g}}$ & $\begin{array}{l}\text { generator heat transfer rate in EJC }(\mathrm{W}) \\
\text { temperature }\left({ }^{\circ} \mathrm{C}\right)\end{array}$ \\
\hline$A_{\mathrm{t}}$ & $\begin{array}{l}\text { cross-section area of the nozzle throat of the } \\
\text { ejector }\left(\mathrm{m}^{2}\right)\end{array}$ & $T_{\mathrm{c}}$ & $\begin{array}{l}\text { condensing temperature of the } \mathrm{RAC} / \mathrm{MC} \\
\left({ }^{\circ} \mathrm{C}\right)\end{array}$ \\
\hline$C O P_{1}$ & $\begin{array}{l}\text { coefficient of performance of single-cycle } \\
\text { refrigeration system using mechanical com- } \\
\text { pressor (RAC/MC) }\end{array}$ & $\begin{array}{l}T_{\mathrm{c}}^{\prime} \\
T_{\text {comp }}\end{array}$ & $\begin{array}{l}\text { condensing temperature of the } \mathrm{EJC}\left({ }^{\circ} \mathrm{C}\right) \\
\text { compressor discharge temperature of the } \\
\text { RAC/MC }\left({ }^{\circ} \mathrm{C}\right)\end{array}$ \\
\hline $\mathrm{COP}_{2}$ & $\begin{array}{l}\text { coefficient of performance of combined- } \\
\text { cycle refrigeration system using mechanical }\end{array}$ & $T_{\mathrm{e}}$ & $\begin{array}{l}\text { evaporating temperature of the } \mathrm{RAC} / \mathrm{MC} \\
\left({ }^{\circ} \mathrm{C}\right)\end{array}$ \\
\hline & $\begin{array}{l}\text { compressor (RAC/MC) and ejector cooling } \\
\text { cycle (EJC) }\end{array}$ & $T_{\mathrm{e}}^{\prime}$ & $\begin{array}{l}\text { evaporating temperature of the ejector cycle } \\
\left(\text { EJC) }\left({ }^{\circ} \mathrm{C}\right)\right.\end{array}$ \\
\hline$d_{3}$ & $\begin{array}{l}\text { diameter of the constant-area section in } \\
\text { ejector }(\mathrm{m})\end{array}$ & $\begin{array}{l}T_{\mathrm{g}} \\
W_{\mathrm{c}}\end{array}$ & $\begin{array}{l}\text { generating temperature of the EJC }\left({ }^{\circ} \mathrm{C}\right) \\
\text { compressor power consumption }(\mathrm{W})\end{array}$ \\
\hline $\begin{array}{l}d_{\mathrm{t}} \\
C_{\mathrm{p}}\end{array}$ & $\begin{array}{l}\text { diameter of the nozzle throat in ejector }(\mathrm{m}) \\
\text { specific heat of liquid working fluid in } \mathrm{RAC} /\end{array}$ & $W_{\text {pump }}$ & $\begin{array}{l}\text { pumping power of pump in ejector-cooling } \\
\text { cycle (W) }\end{array}$ \\
\hline$C_{\mathrm{p}}^{\prime}$ & $\begin{array}{l}\mathrm{MC}\left(\mathrm{J} \mathrm{kg}^{-1} \mathrm{~K}\right) \\
\text { specific heat of liquid working fluid in EJC } \\
\left(\mathrm{J} \mathrm{kg}^{-1} \mathrm{~K}\right)\end{array}$ & $\begin{array}{l}\gamma_{\mathrm{p}} \\
\omega\end{array}$ & $\begin{array}{l}\text { compression ratio of the EJC, } P_{\mathrm{c}}^{\prime} / P_{\mathrm{e}}^{\prime} \\
\text { ejector entrainment ratio (dimensionless) }\end{array}$ \\
\hline$h$ & enthalpy of working fluid $\left(\mathrm{J} \mathrm{kg}^{-1}\right)$ & & \\
\hline$h_{\mathrm{g}}$ & thermodynamic function of enthalpy for & Subscri & \\
\hline$h_{\mathrm{gs}}$ & $\begin{array}{l}\text { vapor state }\left(\mathrm{J} \mathrm{kg}^{-1}\right) \\
\text { thermodynamic function of enthalpy for }\end{array}$ & $1,2 \ldots$ & $\begin{array}{l}\text { thermodynamic state for the process shown } \\
\text { in Fig. } 1\end{array}$ \\
\hline & saturated-vapor state $\left(\mathrm{J} \mathrm{kg}^{-1}\right)$ & $\mathrm{c}$ & condenser \\
\hline$h_{\mathrm{f}}$ & thermodynamic function of enthalpy for & $\mathrm{e}$ & evaporator \\
\hline & saturated-liquid state $\left(\mathrm{J} \mathrm{kg}^{-1}\right)$ & $\mathrm{g}$ & generator \\
\hline$m_{\mathrm{e}}$ & $\begin{array}{l}\text { mass flowrate of working fluid in RAC/MC } \\
\left(\mathrm{kg} \mathrm{s}^{-1}\right)\end{array}$ & $\begin{array}{l}\text { NG } \\
\text { NS }\end{array}$ & $\begin{array}{l}\text { neck point in generator } \\
\text { neck point in subcooler }\end{array}$ \\
\hline$m_{\mathrm{e}}^{\prime}$ & $\begin{array}{l}\text { mass flowrate of the ejector suction flow in } \\
\text { EJC }\left(\mathrm{kg} \mathrm{s}^{-1}\right)\end{array}$ & $\begin{array}{l}\mathrm{pc} \\
\mathrm{SC}\end{array}$ & $\begin{array}{l}\text { precooler } \\
\text { subcooling }\end{array}$ \\
\hline$m_{\mathrm{p}}^{\prime}$ & $\begin{array}{l}\text { mass flowrate of the ejector primary flow in } \\
\text { EJC }\left(\mathrm{kg} \mathrm{s}^{-1}\right)\end{array}$ & & \\
\hline$P_{\mathrm{c}}$ & condensing pressure of $\mathrm{RAC} / \mathrm{MC}(\mathrm{Pa})$ & Supers & ipts \\
\hline$P_{\mathrm{c}}^{\prime}$ & condensing pressure of EJC $(\mathrm{Pa})$ & & ejector-cooling cycle (EJC) \\
\hline $\begin{array}{l}P_{\mathrm{c}}^{*} \\
P_{\mathrm{e}}\end{array}$ & $\begin{array}{l}\text { critical condensing pressure of ejector }(\mathrm{Pa}) \\
\text { evaporating pressure of RAC/MC }(\mathrm{Pa})\end{array}$ & * & critical back pressure condition in ejector \\
\hline
\end{tabular}

\section{Introduction}

The design and operation of a conventional refrigeration and air-conditioning system using mechanical compressor (RAC/MC) follows the inverse of thermodynamic Rankine cycle. It is well known that subcooling the liquid condensate in a reverse Rankine cycle can increase the COP of a refrigeration system. On the other hand, the compressor outlet temperature in a $\mathrm{RAC} / \mathrm{MC}$ is high. A plenty amount of high-grade waste energy must be rejected to the environment.

In the present study, we develop a combined-cycle refrigeration system (CCRS) utilizing a heat-driven ejector-cooling device (EJC) as the bottom cycle of the $\mathrm{RAC} / \mathrm{MC}$. The ejector-cooling device is driven thermally by the waste heat of the condenser in the RAC/ MC. The cooling capacity obtained from the ejectorcooling device is in turn used to cool the liquid condensate of the RAC/MC to a subcooled state to increase the COP of the RAC/MC (see Fig. 1 for the process). The RAC/MC acts as the top cycle and the EJC acts as the bottom cycle in a CCRS. The heat transfer between these two cycles is linked through an inter-connecting heat transfer unit that is composed of a subcooler for subcooling the refrigerant liquid in the RAC/MC and a generator for vapor generation in the EJC. A precooler 


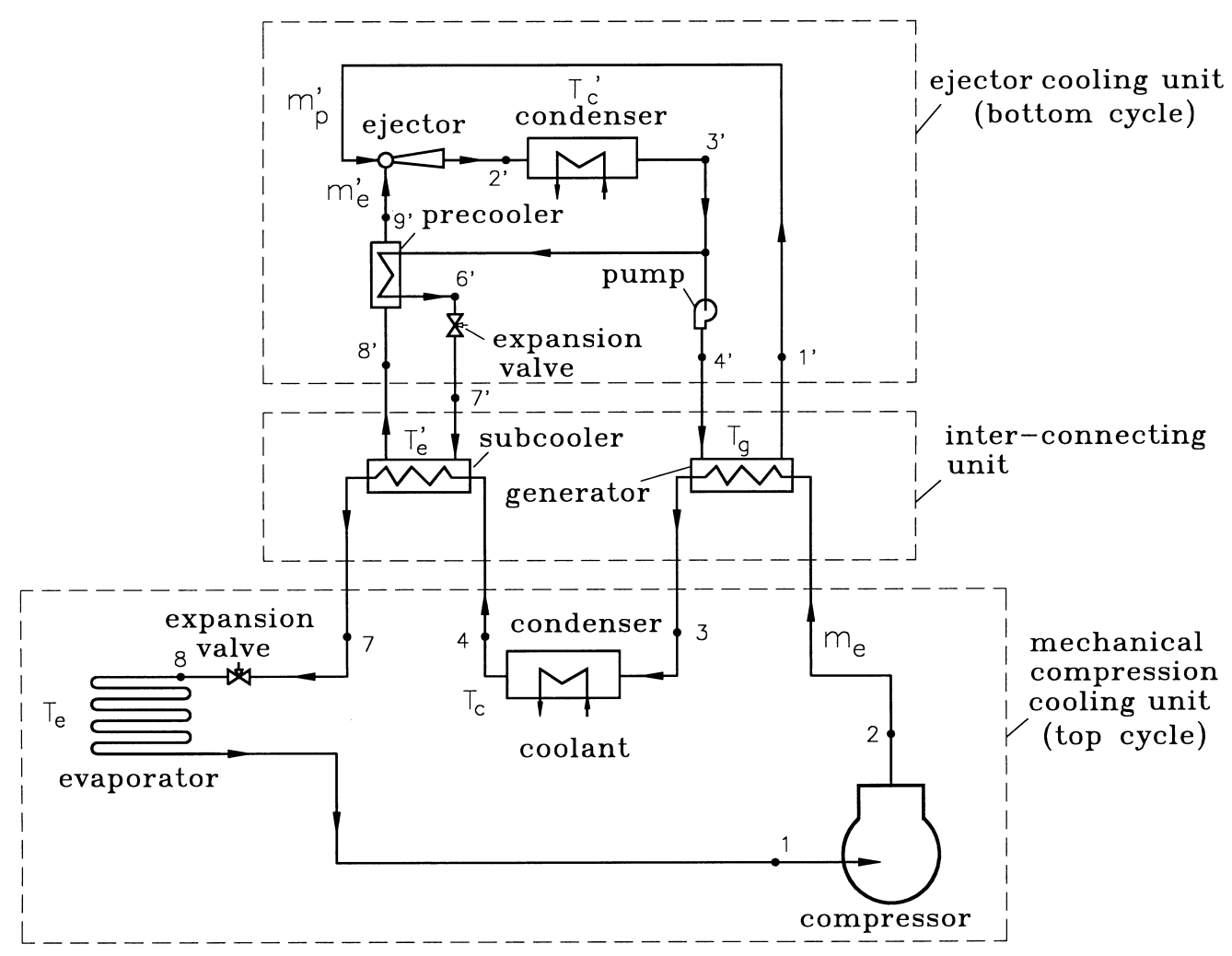

Fig. 1. Schematic diagram of a combined-cycle refrigeration system (CCRS).

Fig. 1. Schéma d'un cycle frigorifique mixte (CCRS).

is used in the EJC to increase the performance of ejector. In this paper, we present the system analysis as well as the test results of a prototype to verify the feasibility of a CCRS.

\section{System analysis of the combined-cycle refrigeration system}

A system analysis of the combined-cycle refrigeration system (CCRS) is carried out in the present study. Governing equations based on the conservation of energy and mass are derived for every component of the CCRS.

\subsection{Governing equations of the components in CCRS}

\subsubsection{Subcooler}

The subcooler is used to subcool the liquid condensate in the RAC/MC by using the evaporation heat of the EJC. The subcooler is basically a heat exchanger like an evaporator with the refrigerant in the EJC undergoing an evaporating process. We assume that the thermodynamic state at the exit of the subcooler (state $8^{\prime}$ ) for the EJC is a saturated-vapor state and the neckpoint (state $7^{\prime}$ ) temperature difference of the subcooler is $\Delta T_{\mathrm{NS}} . \Delta T_{\mathrm{NS}}$ is given as the heat exchanger design parameter. Therefore, we obtain the following governing equations:

$T_{8}^{\prime}=T_{\mathrm{e}}^{\prime}=T_{7}^{\prime}$

$T_{7}=T_{7}^{\prime}+\Delta T_{\mathrm{NS}}$

$h_{8}^{\prime}=h_{\mathrm{gs}}\left(T_{8}^{\prime}\right)$;

$h_{7}^{\prime}=h_{6}^{\prime} \quad$ (throttling process in expansion valve);

$Q_{\mathrm{e}}^{\prime}=m_{\mathrm{e}}^{\prime}\left(h_{8}^{\prime}-h_{7}^{\prime}\right)$

$Q_{\mathrm{e}}=m_{\mathrm{e}}\left(h_{4}-h_{7}\right)$

$Q_{\mathrm{e}}^{\prime}=Q_{\mathrm{e}}=m_{\mathrm{e}}^{\prime}\left(h_{8}^{\prime}-h_{7}^{\prime}\right)=m_{\mathrm{e}}\left(h_{4}-h_{7}\right)$. 


\subsubsection{EJC condenser}

Assume that the condensate at the exit of the condenser (state $3^{\prime}$ ) in the EJC is at saturated-liquid state. The governing equations of the EJC condenser are

$$
\begin{aligned}
& T_{3}^{\prime}=T_{\mathrm{c}}^{\prime} \\
& P_{\mathrm{c}}^{\prime}=P\left(T_{\mathrm{c}}^{\prime}\right) \\
& h_{3}^{\prime}=h_{\mathrm{gs}}\left(T_{\mathrm{c}}^{\prime}\right) \\
& h_{2}^{\prime}=h_{g}\left(T_{2}^{\prime}, P_{\mathrm{c}}^{\prime}\right) \\
& Q_{\mathrm{c}}^{\prime}=\left(m_{\mathrm{p}}^{\prime}+m_{e}^{\prime}\right)\left(h_{2}^{\prime}-h_{3}^{\prime}\right)
\end{aligned}
$$

\subsubsection{Generator}

In the generator, the refrigerant in the EJC undergoes a phase-change process (evaporation) and the refrigerant in the $\mathrm{RAC} / \mathrm{MC}$ undergoes a cooling process at vapor state. The generator is thus a heat exchanger like an evaporator. The neck-point temperature difference of the generator is $\Delta T_{\mathrm{NG}}$ which is a given design parameter for the generator. Denoting the state at the neck point as state 02 for the RAC/MC refrigerant vapor and as state $01^{\prime}$ for the EJC, we obtain the following governing equations:

$T_{02}=T_{g}+\Delta T_{\mathrm{NG}}$

$m_{\mathrm{e}}\left(h_{02}-h_{3}\right)=m_{\mathrm{e}}^{\prime}\left(h_{01}^{\prime}-h_{4}^{\prime}\right)$

where $h_{02}=h_{\mathrm{g}}\left(T_{02}, P_{\mathrm{c}}\right) ; h_{2}=h_{\mathrm{g}}\left(T_{2}, P_{\mathrm{c}}\right) ; h_{01}^{\prime}=h_{\mathrm{f}}\left(T_{01}^{\prime}\right)$;

$T_{01}^{\prime}=T_{\mathrm{g}}$

$T_{4}^{\prime}=T_{3}^{\prime}=T_{\mathrm{c}}^{\prime}$

$h_{4}^{\prime}=h_{01}^{\prime}-C_{\mathrm{p}}^{\prime}\left(T_{01}^{\prime}-T_{4}^{\prime}\right)=h_{01}^{\prime}-C_{p}^{\prime}\left(T_{\mathrm{g}}-T_{\mathrm{c}}^{\prime}\right)$

$m_{\mathrm{e}}\left(h_{2}-h_{02}\right)=m_{\mathrm{e}}^{\prime}\left(h_{1}^{\prime}-h_{01}^{\prime}\right)$

$\frac{m_{\mathrm{e}}^{\prime}}{m_{\mathrm{e}}}=\frac{h_{2}-h_{02}}{h_{1}^{\prime}-h_{01}^{\prime}}=\frac{h_{02}-h_{3}}{h_{01}^{\prime}-h_{4}^{\prime}}$

$Q_{\mathrm{g}}=Q_{\mathrm{g}}^{\prime}=m_{\mathrm{e}}\left(h_{2}-h_{3}\right)=m_{\mathrm{e}}^{\prime}\left(h_{1}^{\prime}-h_{4}^{\prime}\right)$.

\subsection{4. $R A C / M C$ condenser}

Assuming that the condenser of the $\mathrm{RAC} / \mathrm{MC}$ has a degree of sub-cooling, $\Delta T_{\mathrm{SC}}$, the governing eqations are

$Q_{\mathrm{c}}=m_{\mathrm{e}}\left(h_{3}-h_{4}\right)$

$$
\begin{aligned}
& h_{3}=h_{\mathrm{g}}\left(P_{\mathrm{c}}, T_{3}\right) \\
& T_{4}=T_{\mathrm{c}}-\Delta T_{\mathrm{SC}} . \\
& h_{4}=h_{\mathrm{f}}\left(T_{\mathrm{c}}\right)-C_{\mathrm{p}} \Delta T_{\mathrm{SC}}
\end{aligned}
$$

\subsubsection{EJC precooler}

The precooler in the EJC is a simple heat exchanger that can be characterized by the effectiveness:

$\epsilon_{\mathrm{pc}}=\frac{T_{3}^{\prime}-T_{6}^{\prime}}{T_{3}^{\prime}-T_{8}^{\prime}}$

$\epsilon_{\mathrm{pc}}$ is a given design parameter in the precooler design. Eq. 25 can be used to determine a temperature if the rest two temperatures are known.

\subsubsection{EJC ejector}

The ejector performance can be predicted by a 1-D analysis [1] or by empirical correlations. Huang and Chang [2] experimentally show that the entrainment ratio of the ejector $\omega$ can be represented by an effective area ratio, $A_{\mathrm{e}} / A_{\mathrm{t}}$, and the required ejector area ratio $A_{3} /$ $A_{\mathrm{t}}$ is a function of critical condensing pressure $P_{\mathrm{c}}^{\prime}$ and the generating pressure $P_{\mathrm{g}}$. Here, $A_{\mathrm{e}}$ represents a hypothetical throat area for the entrained flow of the ejector at choking condition; $A_{\mathrm{t}}$ is the throat area of the nozzle of the ejector. Empirical correlations for $A_{\mathrm{e}} / A_{\mathrm{t}}$ and $A_{3} /$ $A_{\mathrm{t}}$ were found by Huang and Chang [2] for ejector operated with refrigerant R141b, where $A_{3}$ is the crosssection area of the constant-area section of the ejector. Huang and Chang [2] derived the following relations for the calculation of the ejector entrainment ratio:

$$
\begin{aligned}
\frac{A_{\mathrm{e}}}{A_{\mathrm{t}}}= & -0.0517\left(\frac{A_{3}}{A_{\mathrm{t}}}\right)^{2}+1.4362\left(\frac{A_{3}}{A_{\mathrm{t}}}\right)-4.1734 \\
\frac{A_{3}}{A_{\mathrm{t}}}= & f_{\mathrm{a}}\left(\frac{P_{\mathrm{c}}^{\prime}}{P_{\mathrm{e}}^{\prime}}, \frac{P_{\mathrm{g}}}{P_{\mathrm{e}}^{\prime}}\right) \\
= & b_{0}+b_{1} r_{\mathrm{c}}+b_{2} r_{\mathrm{c}}^{2}+b_{3} r_{\mathrm{g}}+b_{4} r_{\mathrm{c}} r_{\mathrm{g}}+b_{5} r_{\mathrm{c}}^{2} r_{\mathrm{g}} \\
& +b_{6} r_{\mathrm{g}}^{2}+b_{7} r_{\mathrm{c}} r_{\mathrm{g}}^{2}+b_{8} r_{\mathrm{c}}^{2} r_{\mathrm{g}}^{2}
\end{aligned}
$$

where $r_{\mathrm{c}}=P_{\mathrm{c}}^{*} / P_{\mathrm{e}}^{\prime} ; r_{\mathrm{g}}=P_{\mathrm{g}} / P_{\mathrm{e}}^{\prime} ; b_{\mathrm{o}}=5.4497 ; b_{1}=-6.7759$; $b_{2}=1.4952 ; b_{3}=2.3116 ; b_{4}=-0.590 ; b_{5}=0.018105 ; b_{6}=$ $-0.03786 ; b_{7}=0.012983 ; b_{8}=-0.000812145$. Assuming that $P_{\mathrm{c}}^{*}=P_{\mathrm{c}}^{\prime}$, and using the above correlations and the calculation procedure derived by Huang and Chang [2], the entrainment ratio of the ejector can be determined.

From energy balance, the following governing equations are also obtained:

$h_{2}^{\prime}=\frac{h_{1}^{\prime}+\omega h_{9}^{\prime}}{1+\omega}$ 
$T_{2}^{\prime}=h_{\mathrm{g}}\left(P_{\mathrm{c}}^{\prime}, h_{2}^{\prime}\right)$

where $\omega=m_{\mathrm{e}}^{\prime} / m_{\mathrm{p}}^{\prime}$.

\subsection{7. $R A C / M C$ compressor}

The compressor undergoes a non-isentropic process for vapor compression. The power input to the compressor can be represented by the following equation:

$W_{\mathrm{c}}=m_{\mathrm{e}}\left(h_{2}-h_{1}\right) / \eta_{\mathrm{c}}$

where $\eta_{\mathrm{c}}$ is the compression efficiency, including the motor loss. The outlet temperature $T_{2}$ of the compressor can be determined by thermodynamic equation of state:

$T_{2}=f\left(h_{2}, P_{\mathrm{c}}\right)$

where

$h_{2}=h_{1}+\left(h_{2 \mathrm{~s}}-h_{1}\right) / \eta_{\mathrm{s}}$

$h_{2 \mathrm{~s}}=h_{\mathrm{g}}\left(T_{2 \mathrm{~s}}, P_{\mathrm{c}}\right)$

$T_{2 \mathrm{~s}}=h_{\mathrm{g}}\left(P_{\mathrm{c}}, s_{2}=s_{1}\right)$

$\eta_{\mathrm{s}}$ is the isentropic efficiency of the compression process.

\subsection{System analysis of a CCRS}

Using the above governing equations, a system performance calculation based on the concept of informationflow diagram [3] can be carried out. The informationflow diagram shows that there are three independent design variables for a CCRS, namely, the condensing temperature $T_{\mathrm{c}}$ and the evaporating temperature $T_{\mathrm{e}}$ of the RAC/MC, and the evaporating temperature $T_{\mathrm{e}}^{\prime}$ of the EJC. Given $T_{\mathrm{c}}, T_{\mathrm{e}}, T_{\mathrm{e}}$ and the performance maps of the ejector and the compressor, the system performance of a CCRS can be carried out.

In the present study, we use R22 as the working fluid in the RAC/MC and R141b as the working fluid in the EJC. Eqs. (26) and (27) are used for ejector performance calculation in system analysis since R141b is used in EJC. The RAC/MC uses a reciprocating-type compressor S34UP which is made by Electrolux. The rated power is $1-7 / 8 \mathrm{HP}$ and the swept volume of the piston is $34 \mathrm{~cm}^{3}$. The compressor efficiency $\eta_{\mathrm{c}}$ was separately determined by an experiment and the following empirical relation is obtained:

$\eta_{\mathrm{c}}=0.9172-0.1031\left(P_{\mathrm{c}} / P_{\mathrm{e}}\right)$

The coefficient of performance of the combined-cycle refrigeration system, $\mathrm{COP}_{2}$, is determined by the following definition:

$C O P_{2}=\frac{Q_{\mathrm{e}}}{W_{\mathrm{c}}+W_{\text {pump }}}$,

where $W_{\text {pump }}$ is the pumping power consumed by the circulation pump in the EJC. For comparison, the coefficient of performance of the single-cycle refrigeration system (RAC/MC), $C O P_{1}$, is determined. $C O P_{1}$ is defined as

$C O P_{1}=\frac{Q_{\mathrm{e}}}{W_{\mathrm{c}}}$.

The analytical results presented in Table 1 show that the COP of a CCRS is superior to that of a single-cycle system (RAC/MC). It can be seen that the improvement of COP is more significant at higher condensing temperature of the RAC/MC $T_{\mathrm{c}}$. For $T_{\mathrm{e}}=-5^{\circ} \mathrm{C}$, the improvement in COP by using a CCRS can be as high as $18.4 \%$ at $T_{\mathrm{c}}=50^{\circ} \mathrm{C}$ and $T_{\mathrm{e}}^{\prime}=20^{\circ} \mathrm{C}$ (evaporating temperature of the EJC). Fig. 2 shows that the ejector

Table 1

Analytical results for COP of single-cycle and combined-cycle systems at $T_{\mathrm{e}}=-5^{\circ} \mathrm{C}$

Tableau 1

COP de systèmes simples et mixtes à une température $T_{e}$ de $-5^{\circ} \mathrm{C}$ : résultats de l'analyse

\begin{tabular}{|c|c|c|c|c|c|c|c|}
\hline \multirow{2}{*}{$\begin{array}{l}R 22 \text { condensing } \\
\text { temperature } T_{\mathrm{c}}\left({ }^{\circ} \mathrm{C}\right)\end{array}$} & \multirow{2}{*}{$\begin{array}{l}\text { Single-cycle } \\
\text { system } C O P_{1}\end{array}$} & \multicolumn{2}{|c|}{$T_{\mathrm{e}}^{\prime}=20^{\circ} \mathrm{C}$} & \multicolumn{2}{|c|}{$T_{\mathrm{e}}^{\prime}=22^{\circ} \mathrm{C}$} & \multicolumn{2}{|c|}{$T_{\mathrm{e}}^{\prime}=24^{\circ} \mathrm{C}$} \\
\hline & & $\mathrm{COP}_{2}$ & $\triangle C O P_{\mathrm{imp}}{ }^{\mathrm{a}}(\%)$ & $\mathrm{COP}_{2}$ & $\triangle C O P_{\mathrm{imp}}{ }^{\mathrm{a}}(\%)$ & $\mathrm{COP}_{2}$ & $\triangle C O P_{\mathrm{imp}}{ }^{\mathrm{a}}(\%)$ \\
\hline 35 & 2.33 & 2.50 & 7.3 & 2.48 & 6.2 & 2.45 & 5.2 \\
\hline 38 & 2.11 & 2.31 & 9.5 & 2.29 & 8.1 & 2.26 & 7.0 \\
\hline 40 & 1.98 & 2.20 & 11.1 & 2.17 & 9.5 & 2.15 & 8.6 \\
\hline 42 & 1.83 & 2.05 & 12.0 & 2.03 & 10.9 & 2.01 & 9.8 \\
\hline 45 & 1.64 & 1.88 & 14.6 & 1.86 & 13.3 & 1.84 & 12.2 \\
\hline 47 & 1.53 & 1.77 & 15.7 & 1.75 & 14.8 & 1.73 & 13.1 \\
\hline 50 & 1.36 & 1.61 & 18.4 & 1.59 & 17.2 & 1.57 & 15.4 \\
\hline
\end{tabular}

a $\triangle C O P_{\mathrm{imp}}=\left(C O P_{2}-C O P_{1}\right) / C O P_{1} \times 100 \%$. 
entrainment ratio $\omega$ increases with increasing $T_{\mathrm{c}}$ and $T_{\mathrm{e}}^{\prime}$. The required ejector area ratio $A_{3} / A_{\mathrm{t}}$ increases with increasing $T_{\mathrm{c}}$ and decreasing $T_{\mathrm{e}}^{\prime}$ as shown in Figs. 3. Figs. 4 and 5 show that the cooling capacity $Q_{\mathrm{e}}$ and the COP of a CCRS is superior to that of a single-cycle system. The higher the condensing temperature $T_{\mathrm{c}}$, the better the improvement in COP by using a CCRS. This indicates that a CCRS may be more significant for an ice-storage air-conditioning system using a condenser with air cooling device.

\section{Prototype design and test of a combined-cycle refrigeration system}

\subsection{Prototype design}

A prototype was designed based on the previous system analysis. The design point of the prototype is selected for ice-storage air-conditioning application with

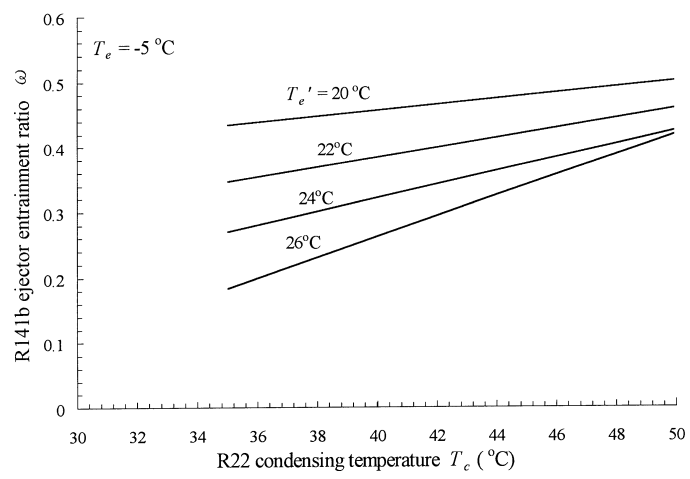

Fig. 2. Theoretical prediction of ejector entrainment ratio $\omega$ in CCRS.

Fig. 2. Taux d'entraînement $\omega$ du CCRS : prévision théorique.

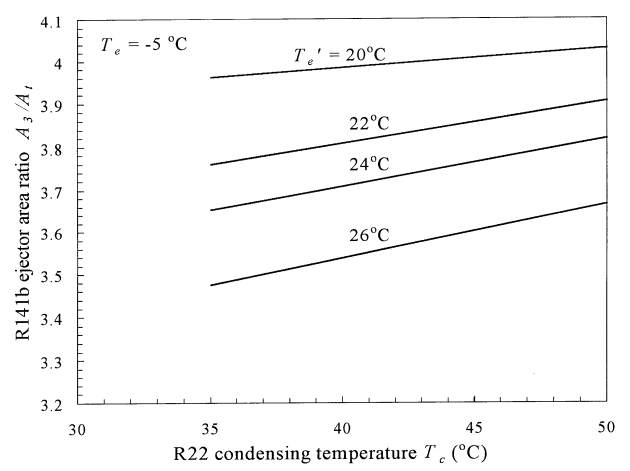

Fig. 3. Theoretical prediction of ejector area ratio $A_{3} / A_{\mathrm{t}}$ in CCRS.

Fig. 3. Prévision théorique de du rapport des sections caractéristiques de l'éjecteur $A_{3} / A_{t} d u$ CCRS.
$T_{\mathrm{e}}=-5^{\circ} \mathrm{C}, \quad T_{\mathrm{c}}=38^{\circ} \mathrm{C}, \quad T_{\mathrm{e}}^{\prime}=20^{\circ} \mathrm{C}, \quad T_{\mathrm{c}}^{\prime}=32.5^{\circ} \mathrm{C} \quad$ and $T_{\mathrm{g}}=68^{\circ} \mathrm{C}$. The design-point specification of the prototype is summarized in Table 2.

\subsection{Prototype test}

The facilities used to measure the cooling capacity $Q_{\mathrm{e}}$ of the prototype, the flowrate of R141b, the temperature and pressure of the cycle at various position, etc., are all the same as described in the previous paper [2].

First of all, we compare the test results of the CCSR with the system analysis at experimental values of $T_{\mathrm{e}}^{\prime}$ and $T_{\mathrm{c}}$, including off-design conditions. Table 3 shows that the analytical results are slightly higher than the test results, within $20 \%$ error for $\mathrm{COP}_{2}$ at $T_{\mathrm{e}}=+5^{\circ} \mathrm{C}$ and within $13 \%$ for $\mathrm{COP}_{2}$ at $T_{\mathrm{e}}=-5^{\circ} \mathrm{C}$. This is due to the heat loss in the pipelines and the heat exchangers

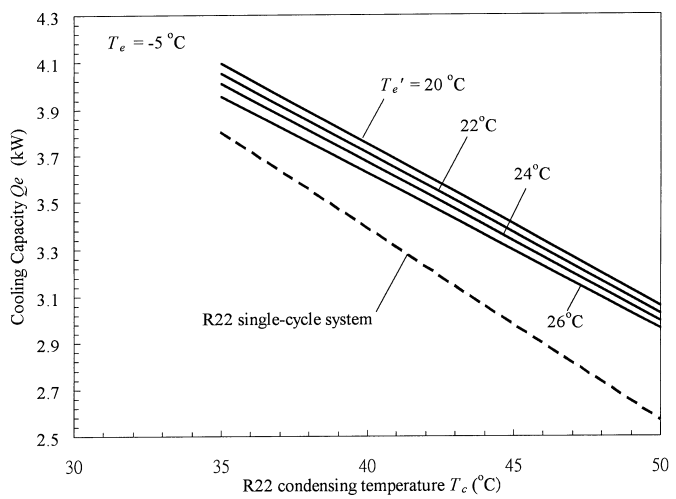

Fig. 4. Theoretical prediction of cooling capacity $Q_{\mathrm{e}}$ for CCRS and $\mathrm{RAC} / \mathrm{MC}$.

Fig. 4. Prévision théorique de la puissance frigorifique $Q_{e}$ pour le CCRS et le RAC/MC.

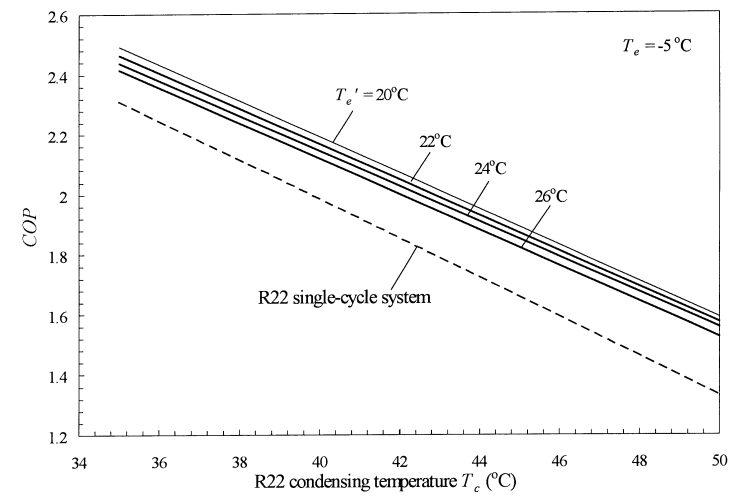

Fig. 5. Theoretical prediction of cooling capacity $C O P$ for CCRS and RAC/MC.

Fig. 5. Prévision théorique du COP, en termes de puissance frigorifique, pour le CCRS et le RAC/MC. 
that are not well insulated. The pressure loss in pipelines and heat exchanger is also a factor causing the analytical error.

Table 4 presents the test results of single-cycle and combined-cycle refrigeration systems at $T_{\mathrm{e}}=-4.5^{\circ} \mathrm{C}$. The operating conditions in the tests include the offdesign conditions. It is seen from Table 4 that the improvement in COP of the CCRS is in the range 9$14 \%$. The entrainment ratio $\omega$ of the R $141 \mathrm{~b}$ ejector varies from 0.5 to 0.77 and the COP of the EJC is 0.43 0.67 for compression ratio $\gamma_{\mathrm{p}}$ of the ejector from 1.22 to 1.67 .

Table 2

Design specifications of the prototype

Tableau 2

Spécifications du prototype

1. R22 compressor cycle ( $R A C / M C)$

Compressor

Electrolux S34UP (1-7/8 HP), $34 \mathrm{~cm}^{3}$

Evaporator

$5.2 \mathrm{~kW}$ flat-plate type

Condenser

$7.1 \mathrm{~kW}$ flat-plate type, water cooling

Expansion device

$1.4 \mathrm{~mm}$ ID capillary tube, $80 \mathrm{~cm}$

2. R141b ejector cooling cycle (EJC)

Ejector $\quad d_{\mathrm{t}}=1.6 \mathrm{~mm} ; d_{3}=4.0 \mathrm{~mm}$

Evaporator $\quad 1.9 \mathrm{~kW}$ flat-plate type

Condenser $\quad 4.6 \mathrm{~kW}$ flat-plate type, water cooling

Precooler

Expansion device $\quad 3 / 8$ " adjustable expansion valve

R141b pump

$51 /$ min, gear pump

3. Design-point performance of combined-cycle system Cooling capacity $Q_{\mathrm{e}} \quad 3.9 \mathrm{~kW}$

$\mathrm{COP}_{2}$

2.31

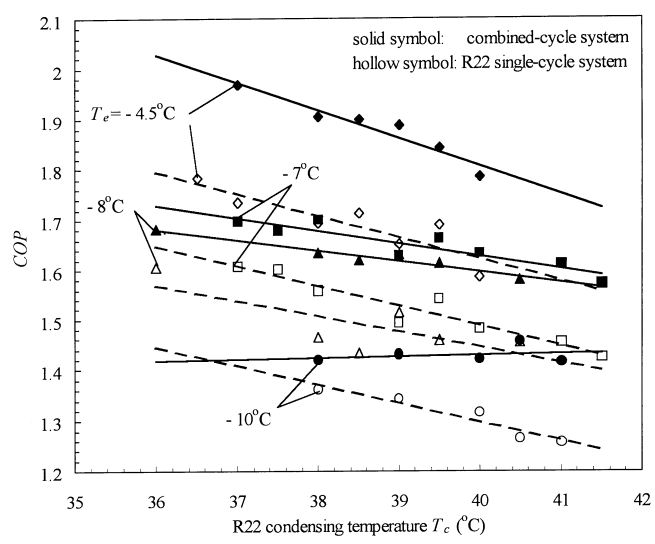

Fig. 6. Experimental results of a combined-cycle refrigeration system for $T_{\mathrm{e}}$ from -10 to $-4.5^{\circ} \mathrm{C}$.

Fig. 6. Résultats expérimentaux d'un système frigorifique mixte pour les $T_{e}$ allant de $-10 \grave{a}-4,5^{\circ} \mathrm{C}$.
The off-design test is also performed at $T_{\mathrm{e}}=5^{\circ} \mathrm{C}$. Table 5 shows that the COP improvement of the CCRS is in the range of $15-24 \%$. The entrainment ratio $\omega$ of the R141b ejector is from 0.51 to 0.90 and the COP of the EJC is $0.46-0.80$ for ejector compression ratio $\gamma_{\mathrm{p}}$ from 1.12 to 1.19 . It is seen that the performance improvement of a CCRS has the highest value at high $T_{\mathrm{c}}$. This coincides with the theoretical prediction and indicates that the CCRS may be more significant if used in an air-conditioning system with air-cooled condenser.

Test results for various off-design conditions are shown in Figs. 6 and 7 for various $T_{\mathrm{e}}$ and $T_{\mathrm{c}}$. From these results, we may conclude that the CCRS can significantly improve the performance of a single-cycle refrigeration system (RAC/MC).

\section{Discussion and conclusion}

The use of the ejector cooling cycle (EJC) as the bottom cycle of an inverse Rankine cycle using mechanical compressor (RAC/MC) to lead to a combined-cycle refrigeration system (CCRS) is a new concept. Since the ejector-cooling cycle is driven using the waste heat from the $\mathrm{RAC} / \mathrm{MC}$, no additional energy is required except the negligible pumping power in the EJC. The improvement in COP for a CCRS is thus expected. Both the system simulation and the experimental results obtained in the present study verify this concept. The improvement of COP for the present laboratory-made prototype with small capacity and tested at off-design conditions can be as large as $24 \%$, and are mostly greater than $10 \%$ depending upon the operating conditions. Further improvement in COP is possible since the prototype is

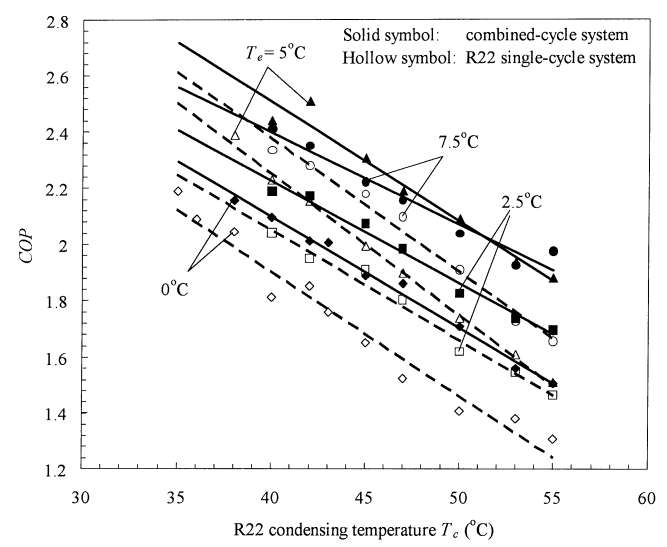

Fig. 7. Experimental results of a combined-cycle refrigeration system for $T_{\mathrm{e}}$ from 0 to $7.5^{\circ} \mathrm{C}$.

Fig. 7. Résultats expérimentaux d'un système frigorifique mixte pour les $T_{e}$ allant de $0 \grave{a}+7,5^{\circ} \mathrm{C}$. 
Comparison of analytical and test results for a combined-cycle refrigeration system at $T_{\mathrm{e}}=-5$ and $+5^{\circ} \mathrm{C}$

Tableau 3

Comparaison des résultats analytiques et d'essais pour un système frigorifique mixte pour $T_{e}=-5$ et $+5^{\circ} \mathrm{C}$

\begin{tabular}{|c|c|c|c|c|c|c|c|c|c|}
\hline \multirow{2}{*}{$\begin{array}{l}\mathrm{R} 22 \text { condensing } \\
\text { temperature } T_{\mathrm{c}}\left({ }^{\circ} \mathrm{C}\right)\end{array}$} & \multicolumn{3}{|c|}{ Cooling capacity $Q_{\mathrm{e}}(\mathrm{kW})$} & \multicolumn{3}{|c|}{ Compressor input power $W_{\mathrm{c}}(\mathrm{kW})$} & \multicolumn{3}{|l|}{$\mathrm{COP}_{2}$} \\
\hline & Analysis & Test & Error $^{\mathrm{a}}(\%)$ & Analysis & Test & Error $^{\mathrm{a}}(\%)$ & Analysis & Test & Error $^{\mathrm{a}}(\%$ \\
\hline \multicolumn{10}{|l|}{$T_{\mathrm{e}}=-5^{\circ} \mathrm{C}$} \\
\hline $38\left(T_{\mathrm{e}}^{\prime}=16^{\circ} \mathrm{C}\right)$ & 3.97 & 3.09 & +22.2 & 1.68 & 1.59 & +5.4 & 2.36 & 1.90 & +19.5 \\
\hline $\begin{array}{l}40\left(T_{\mathrm{e}}^{\prime}=21^{\circ} \mathrm{C}\right) \\
T_{\mathrm{e}}=+5^{\circ} \mathrm{C}\end{array}$ & 3.76 & 2.97 & +21.0 & 1.72 & 1.63 & +5.2 & 2.18 & 1.79 & +12.2 \\
\hline $42\left(T_{\mathrm{e}}^{\prime}=27^{\circ} \mathrm{C}\right)$ & 5.65 & 4.83 & +14.5 & 1.98 & 1.87 & +5.6 & 2.86 & 2.51 & +12.2 \\
\hline $45\left(T_{\mathrm{e}}^{\prime}=27^{\circ} \mathrm{C}\right)$ & 5.45 & 4.62 & +15.2 & 2.08 & 1.94 & +6.7 & 2.62 & 2.31 & +11.8 \\
\hline $50\left(T_{\mathrm{e}}^{\prime}=27^{\circ} \mathrm{C}\right)$ & 5.20 & 4.46 & +14.2 & 2.26 & 2.06 & +8.8 & 2.32 & 2.29 & +1.30 \\
\hline
\end{tabular}

${ }^{\mathrm{a}}$ Error $=\left(C O P_{\text {analysis }}-C O P_{\text {test }}\right) / C O P_{\text {analysis }} \times 100 \%$.

Table 4

Comparison of test results for single-cycle and combined-cycle refrigeration systems at $T_{\mathrm{e}}=-4.5^{\circ} \mathrm{C}$

Tableau 4

Comparaison des résultats d'essais sur des systèmes simples et mixtes où $T_{e}=-4,5^{\circ} \mathrm{C}$

\begin{tabular}{|c|c|c|c|c|c|c|c|c|}
\hline \multirow[b]{2}{*}{$\mathrm{R} 22 \mathrm{~T}_{\mathrm{c}}\left({ }^{\circ} \mathrm{C}\right)$} & \multicolumn{4}{|c|}{ R22 single-cycle system } & \multicolumn{4}{|c|}{ Combined-cycle system } \\
\hline & $Q_{\mathrm{e}}(\mathrm{kW})$ & $T_{\text {comp }}\left({ }^{\circ} \mathrm{C}\right)$ & $m_{\mathrm{e}}(\mathrm{kg} / \mathrm{s})$ & $C O P_{1}$ & $Q_{\mathrm{e}}(\mathrm{kW})$ & $\mathrm{COP}_{2}$ & $\triangle C O P_{\mathrm{imp}}(\%)$ & \\
\hline 37 & 2.718 & 104.8 & 0.0155 & 1.735 & 3.131 & 1.969 & 13.53 & \\
\hline 38 & 2.693 & 109.2 & 0.0157 & 1.694 & 3.091 & 1.904 & 12.44 & \\
\hline 38.5 & 2.741 & 106.1 & 0.0156 & 1.714 & 3.071 & 1.898 & 10.76 & \\
\hline 39 & 2.652 & 103.8 & 0.0155 & 1.651 & 3.103 & 1.887 & 14.27 & \\
\hline 39.5 & 2.726 & 106.6 & 0.0163 & 1.690 & 3.026 & 1.843 & 9.03 & \\
\hline \multirow[t]{2}{*}{40} & 2.590 & 107.2 & 0.0150 & 1.586 & 2.966 & 1.785 & 12.56 & \\
\hline & \multicolumn{8}{|c|}{ Performance of R141b ejector-cooling unit at $T_{\mathrm{e}}=-4.5^{\circ} \mathrm{C}$} \\
\hline $\mathrm{R} 22 T_{\mathrm{c}}\left({ }^{\circ} \mathrm{C}\right)$ & $T_{\mathrm{g}}\left({ }^{\circ} \mathrm{C}\right)(\mathrm{kPa})$ & $T_{\mathrm{e}}^{\prime}\left({ }^{\circ} \mathrm{C}\right)(\mathrm{kPa})$ & $T_{\mathrm{c}}^{\prime}\left({ }^{\circ} \mathrm{C}\right)(\mathrm{kPa})$ & $\gamma_{\mathrm{p}}$ & $Q_{\mathrm{e}}^{\prime}(\mathrm{kW})$ & $Q_{\mathrm{g}}^{\prime}(\mathrm{kW})$ & $\omega$ & $C O P_{\mathrm{R} 141 \mathrm{~b}}$ \\
\hline 37 & $70.8(330)$ & $18.5(60.5)$ & $26(80)$ & 1.33 & 0.329 & 0.493 & 0.766 & 0.667 \\
\hline 38 & $71.6(340)$ & $16.0(53.9)$ & $29(90)$ & 1.67 & 0.316 & 0.562 & 0.654 & 0.563 \\
\hline 38.5 & $70.3(330)$ & $16.0(53.9)$ & $29(90)$ & 1.67 & 0.290 & 0.534 & 0.629 & 0.544 \\
\hline 39 & $69.5(320)$ & $18.5(60.5)$ & $29(90)$ & 1.49 & 0.305 & 0.508 & 0.688 & 0.600 \\
\hline 39.5 & $71.5(340)$ & $21.0(67.1)$ & $32(100)$ & 1.49 & 0.256 & 0.556 & 0.531 & 0.462 \\
\hline 40 & $72.3(350)$ & $21.0(67.1)$ & $32(100)$ & 1.49 & 0.216 & 0.497 & 0.501 & 0.434 \\
\hline
\end{tabular}


Table 5

Comparison of test results for single-cycle and combined-cycle refrigeration systems at $T_{\mathrm{e}}=+5^{\circ} \mathrm{C}$

Tableau 5

Comparaison des résultats d'essais sur des systèmes simples et mixtes où $T_{e}=+5^{\circ} \mathrm{C}$

\begin{tabular}{|c|c|c|c|c|c|c|c|c|}
\hline \multirow[b]{2}{*}{$\mathrm{R} 22 \mathrm{~T}_{\mathrm{c}}\left({ }^{\circ} \mathrm{C}\right)$} & \multicolumn{4}{|c|}{ R22 single-cycle system } & \multicolumn{4}{|c|}{ Combined-cycle system } \\
\hline & $Q_{\mathrm{e}}(\mathrm{kW})$ & $T_{\text {comp }}\left({ }^{\circ} \mathrm{C}\right)$ & $m_{\mathrm{e}}(\mathrm{kg} / \mathrm{s})$ & $C O P_{1}$ & $Q_{\mathrm{e}}(\mathrm{kW})$ & $\mathrm{COP}_{2}$ & $\triangle C O P_{\text {imp }}(\%)$ & \\
\hline 42 & 4.01 & 106.4 & 0.0259 & 2.15 & 4.83 & 2.5072 & 16.61 & \\
\hline 45 & 3.91 & 111.8 & 0.0238 & 1.99 & 4.62 & 2.3077 & 15.96 & \\
\hline 47 & 3.80 & 112.3 & 0.0235 & 1.90 & 4.53 & 2.1892 & 15.22 & \\
\hline 50 & 3.60 & 114.7 & 0.0244 & 1.74 & 4.46 & 2.0893 & 20.07 & \\
\hline 53 & 3.44 & 120.6 & 0.0240 & 1.61 & 4.30 & 1.9371 & 20.32 & \\
\hline \multirow[t]{2}{*}{55} & 3.28 & 123.3 & 0.0238 & 1.51 & 4.23 & 1.8793 & 24.46 & \\
\hline & \multicolumn{8}{|c|}{ Performance of R $141 \mathrm{~b}$ ejector-cooling unit at $T_{\mathrm{e}}=5^{\circ} \mathrm{C}$} \\
\hline $\mathrm{R} 22 T_{\mathrm{c}}\left({ }^{\circ} \mathrm{C}\right)$ & $T_{\mathrm{g}}\left({ }^{\circ} \mathrm{C}\right)(\mathrm{kPa})$ & $T_{\mathrm{e}}^{\prime}\left({ }^{\circ} \mathrm{C}\right)(\mathrm{kPa})$ & $T_{\mathrm{c}}^{\prime}\left({ }^{\circ} \mathrm{C}\right)(\mathrm{kPa})$ & $\gamma_{\mathrm{p}}$ & $Q_{\mathrm{e}}^{\prime}(\mathrm{kW})$ & $Q_{\mathrm{g}}^{\prime}(\mathrm{kW})$ & $\omega$ & $C O P_{\mathrm{R} 141 \mathrm{~b}}$ \\
\hline 42 & $70.2(300)$ & $25.5(80.3)$ & $31(94.7)$ & 1.179 & 0.297 & 0.667 & 0.508 & 0.446 \\
\hline 45 & $70.4(310)$ & $27.0(84.2)$ & $32(100)$ & 1.188 & 0.299 & 0.640 & 0.527 & 0.467 \\
\hline 47 & $70.9(300)$ & $27.5(86.8)$ & $31(97.4)$ & 1.122 & 0.366 & 0.626 & 0.668 & 0.585 \\
\hline 50 & $70.3(300)$ & $27.5(86.8)$ & $31(97.4)$ & 1.122 & 0.458 & 0.644 & 0.805 & 0.710 \\
\hline 53 & $72.1(300)$ & $27.5(86.8)$ & $31(97.4)$ & 1.122 & 0.500 & 0.658 & 0.854 & 0.670 \\
\hline 55 & $73.0(300)$ & $27.5(86.8)$ & $31(97.4)$ & 1.122 & 0.545 & 0.679 & 0.897 & 0.802 \\
\hline
\end{tabular}

not designed and tested at an optimal condition. Further experiments using full-scale system $\left(Q_{\mathrm{e}}>5 \mathrm{RT}\right)$ is also needed before field application. It is expected that the performance improvement of a CCRS may even be higher than the present results.

Finally, it is also noted that the feasibility of the CCRS depends on the reliability that is related to the discharge temperature of the compressor. The test results presented in Tables 4 and 5 show that the discharge temperatures $T_{\text {comp }}$ of the compressor are all maintained in a safe region $\left(<125^{\circ} \mathrm{C}\right)$. Actually, for all the test runs, the compressor has never been shut down automatically by the thermal protection device attached to the compressor body. In practice, the compressor discharge temperature will not exceed the limit if the CCRS is carefully designed. This can be achieved by using a good ejector with optimal design and good fabrication technique, a good condensing device of the EJC, good refrigerant for the EJC, the good matching expansion device in the $\mathrm{RAC} / \mathrm{MC}$, or the optimal amount of refrigerant charge in the RAC/MC. A series of test runs for a new prototype built recently reveal that the discharge temperature of the compressor is maintained between $100^{\circ} \mathrm{C}$ and $115^{\circ} \mathrm{C}$ for the similar operating conditions shown in Tables 4 and 5. This assures that a CCRS can be designed to meet the practical requirement on the reliability issue, in addition to increasing the COP.

\section{Acknowledgements}

The present study is supported by National Science Council, ROC, through Grant Nos. NSC88-2212-E002-050 and NSC88-2212-E-002-051.

\section{References}

[1] Huang BJ, Chang JM, Wang CP, Petrenko VA. : A 1-D analysis of ejector performance. International $\mathrm{J}$ Refrigeration 1999;22:354-64.

[2] Huang BJ, Chang JM. Empirical correlation for ejector design. International J Refrigeration 1999;22:379-88.

[3] Huang BJ, Jiang CB, Hu FL. Ejector performance characteristics and design analysis of jet refrigeration systems. Trans ASME, J Engineering for Gas Turbines and Power 1985;107:792-802. 